\title{
Effect of Treatment with Alkaline Hydrogen Peroxide Associated with Extrusion on Color and Hydration Properties of Oat Hulls
}

\author{
Melicia Cintia Galdeano ${ }^{*}$ and Maria Victória Eiras Grossmann \\ Universidade Estadual de Londrina; Departamento de Ciências de Alimentos; meliciacg@hotmail.com; Caixa \\ Postal 6001; 86.051-970; Londrina - PR - Brazil
}

\begin{abstract}
An incomplete factorial design with three independent variables at three levels of variation was used to evaluate the effect of the treatment with alkaline hydrogen peroxide concomitant with extrusion on some properties of oat hulls. The independent variables were hydrogen peroxide level, feed moisture and extrusion temperature. The dependent variables were water retention capacity (WRC), swollen volume (SV) and color. The analysis of variance showed that temperature was the most important variable for the hydration properties. The highest values of WRC and SV were obtained when oat hulls were processed in the condition of $7 \%$ hydrogen peroxide, $32 \%$ feed moisture and $90^{\circ} \mathrm{C}$ extrusion temperature. Modified hulls had a WRC 70\% higher and SV 55\% higher than the untreated material. The instrumental measure of color was conducted to analyze the modifications promoted due to the treatment in this parameter. The highest value of brightness was obtained with $7 \%$ hydrogen peroxide. The modifications in the fibers were accompanied indirectly through hydration properties.
\end{abstract}

Key words: Dietary fiber, oat hulls, chemical modification, functional properties

\section{INTRODUCTION}

Traditionally, oat hulls a byproduct of oat groat milling, are discarded during processing, becoming an environmental pollutant (Stephen et al., 1997). Due to its high fiber content, it becomes an important ingredient that can be incorporated in several food formulations. However, some structural modifications would be necessary since the addition of this material has negative effects on the final products, including gritty texture and poor appearance.

These deleterious effects, in baked foods, can be due to the gluten dilution and the tendency of this material does not hydrate extensively, decreasing swollen capacity. These rigid and incompletely hydrated particles function as inclusions, weakening dough by cutting gluten strands (Gould et al., 1989; Park et al. 1997). The low hydration capacity of this lignocellulosic residue is resulted, fundamentally, from the protective association of lignin and hemicellulose that blocks the entrance of water, and the degree of crystallinity within the cellulose polymer itself (Gould, 1985).

The physical properties of fiber are altered substantially by treatment with alkaline hydrogen peroxide, which acts solubilizing part of the lignin and reducing cellulose crystallinity through rupture of the hydrogen bonding between and into

\footnotetext{
* Author for correspondence
} 
chains, producing a material with more open internal structure. This causes an increase in the water retention capacity and swelling of fiber, getting better, therefore, sensory characteristics of product (Artz et al., 1990; Gould, 1985; Larrea et al., 1997).

Hydrogen peroxide has been used also as bleach agent in the process. According to Inglett (1995), it should be incorporated in about $1-25 \%$ per weight of solids. However, in most published investigations (Gould, 1989; Larrea et al., 1997; Ramaswamy, 1988), the reagent level used was $1 \%$ and Inglett (1995) made reference to that level. Usually, structural modifications of fiber are performed in chemical solutions, in two or more processing stages with extensive washing of material, generating polluent residues. Reaction time can be as long as up to 72 hours, depending on the process temperature and degree of modification (Artz et al., 1990; Gould, 1989; Larrea et al., 1997; Inglett, 1995; Ramaswamy, 1988). Nowadays, extrusion cooking is also applied with the objective of modifying dietary fiber, associated with or without chemical pretreatments (Inglett, 1995; Larrea et al.,1997; Lue et al., 1991).

Aiming to reduce cost and work, simplified processes are becoming more and more interesting for modifications of food products. Therefore, reactive extrusion treatment, combining heat, pressure and mechanical shear, together with alkaline hydrogen peroxide, could be used in the modification of physical structure of the fiber.

The objective of the present investigation was to modify in only one step oat hulls fiber using extrusion cooking associated with chemical treatment (hydrogen peroxide and sodium hydroxide) to obtain a product with maximum hydration capability and clearest color. In addition, the modification undertaken by dietary fiber during the treatment was studied through hydration properties.

\section{MATERIAL AND METHODS}

\section{Material}

Ground oat hulls (Avena sativa) were provided by SL Cereais Alimentos Ltda (Mauá da Serra - PR, Brazil).

\section{Methods}

Moisture (44-15A), protein (46-13), ash (08-01), lipids (30-26), total dietary fiber and soluble and insoluble fractions (32-07) were determined according to AACC approved methods (1990). All determinations were run in triplicate.

\section{Extrusion}

Ground hulls (500g) were conditioned to the desired moisture content, according to the experimental design. The amount of sodium hydroxide necessary to attain $\mathrm{pH}=11.5$ in the conditioned sample was dissolved in the appropriate volume of water before the water was added to the hulls. Material was placed in sealed polyethylene bags and allowed to equilibrate for $24 \mathrm{~h}$ at $8^{\circ} \mathrm{C}$. Hydrogen peroxide, according to experimental design, was sprinkled in the sample. Material was returned to the refrigerator where stayed for 1 hour for moisture equilibration and then was extruded in a single-screw extruder (Cerealtec CT-L15, Brazil). The extruder has a barrel $420 \mathrm{~mm}$ in length, $19.4 \mathrm{~mm}$ in diameter, three heating zones, 1:2 compression ratio screw and $8 \mathrm{~mm}$ die diameter. Processing temperature in zone 1 was kept constant at $70^{\circ} \mathrm{C}$. The temperatures of zones 2 and 3 were the same and varied according to experimental design. Screw speed $(150 \mathrm{rpm})$ and feeding rate $(70 \mathrm{~g} / \mathrm{min})$ were kept constant.

The extruder was operated at steady state for each set of conditions. Attainment of steady state was judged by constant amperage. Samples were then collected, dried at $50^{\circ} \mathrm{C}$ in a forced-air convection oven to $13 \%$ moisture and then grounded in a Tecnal mill (Tecnal-São Paulo) fitted with a 1.0 $\mathrm{mm}$ screen. The samples were stored in sealed polyethylene bags at room temperature until use.

\section{Properties of Extrudates}

Water retention capacity (WRC) and swollen volume (SV) were determined using the methods described by Robertson et al. (2000). All determinations were run in triplicate. The color of extrudates was measured with Photovolt (model 575), using filter $\mathrm{Y}$ and illuminant $\mathrm{C}$ (6774K), with white calibration standard for $75 \%$ reflectance and black for $0 \%$ reflectance. Determinations were run in triplicate and results were converted to corresponding CIELAB values and expressed as brightness $\left(\mathrm{L}^{*}\right)$. The $\mathrm{pH}$ of extrudate was measured according to AACC method 02-52 (1990). 
Experimental Design - Exploratory modelling An incomplete factorial design was used, with three independent variables at three levels of variation (Box and Benhken, 1960). The independent variables were hydrogen peroxide level (1, 4 and 7\%), feed moisture (26, 29 and $32 \%)$ and extrusion temperature $(110,150$ and $\left.190^{\circ} \mathrm{C}\right)$. The three levels of each variable were coded as $-1,0,+1$, for statistical analysis. Dependent variables were WRC, SV and color. Experimental data were analyzed using the Statistica (Statsoft, Oklahoma) computer software to fit second order polynomial equations to response variables. The models were simplified by backward elimination procedure just keeping significant $(p<0.05)$ terms and others that were judged important for good fitness (Lundstedt et al., 1998). Three-dimensional contour plots were generated from the fitted models, using the same program.

\section{Displacement for More Promising Experimental Area}

The incomplete factorial design indicated a more promising experimental area in the direction of lower temperature and higher moisture and reagent level. Then, new assays were performed varying the temperature $\left(80,90\right.$ and $\left.100^{\circ} \mathrm{C}\right)$ but maintaining the moisture fixed in the superior value tested before (32\%) because the extruder did not work properly in moisture higher than this. The reagent, although pointed for a better effect in concentrations superior to $7 \%$, was kept fixed at this level to be nearer with the level (1\%) recommended by most of the researchers (Gould, 1989; Larrea et al., 1997; Ramaswamy, 1988).
Statistical analyses were performed using the Statistica system (Statsoft, Oklahoma). Data were analyzed by analysis of variance (ANOVA), followed by Tukey's test at the 0.05 level of probability.

\section{Control Experiments}

External controls were also conducted to verify the effect of each isolated processes in the fiber modification: the first one applying the best extrusion condition defined before without reagent and the other one applying only the reagent $(7 \%$ hydrogen peroxide, $\mathrm{pH}=11.5)$, without extrusion.

\section{RESULTS AND DISCUSSION}

\section{Oat Hulls Composition}

An increase of protein and carbohydrate content occurred in oat hulls after treatment, but it could be a relative increase caused by the reduction of other components, principally fiber (Table 1). Generally, the level of soluble fraction of dietary fiber increased with severity of extrusion processing conditions (Robertson, 1998; Qian and Ding, 1996). However, Fornal et al. apud Lue et al. (1991) observed significant decrease of hemicelulose, cellulose and lignin after extrusion, indicating possible thermal decomposition of dietary fiber. This could explain the decrease of total dietary fiber (TDF) on the treated oat hulls. However, this decrease also could be attributed, partly, to the hydrogen peroxide that acted degrading the lignin.

Table 1 - Chemical Composition $(\%, d w b)$ of Untreated and Treated Oat Hulls ${ }^{a}$

\begin{tabular}{lcc}
\hline Oat Hulls & & \\
\hline & Untreated & Treated \\
\hline Protein $(\mathrm{Nx} 6.25)^{\mathrm{b}}$ & 4.30 & 6.75 \\
Ash & 3.50 & 2.77 \\
Lipids & 1.83 & 0.64 \\
TDF $^{\mathrm{c}}$ & 88.05 & 80.13 \\
- Soluble dietary fiber $^{- \text {Insoluble dietary fiber }}$ & 0.74 & 0.73 \\
Nitrogen-free extract ${ }^{\mathrm{d}}$ & 87.31 & 79.40 \\
${ }^{\mathrm{a}}=$ Temperature $=90^{\circ} \mathrm{C} ;$ moisture $=32 \%$ and reagent level $=7 \%{ }^{\mathrm{b}}=$ According to Matz $(1969) ;{ }^{\mathrm{c}}=$ Total Dietary Fiber; ${ }^{\mathrm{d}}=$ By &
\end{tabular}


The reduction of lipid concentration after treatment could be due to the fatty acids oxidation by hydrogen peroxide, generating products that were not detected by analysis method (Larrea et al., 1997).

\section{Effect of Extrusion on Hulls Characteristics}

The results of WRC, SV and color (L*) of extruded oat hulls were used to develop regression models (Table 2). These models were simplified just keeping significant factors $(p<0.05)$ with some exceptions. Linear and quadratic effects of temperature and interactions of temperature and reagent level with moisture influenced WRC. Therefore, the linear effects of reagent level $\left(\mathrm{x}_{1}\right)$ and moisture $\left(\mathrm{x}_{2}\right)$ although nonsignificant, should not be removed during simplification of the mathematic model. Quadratic effect of the reagent level became nonsignificant when the model was simplified, however, for having an important contribution to increase $R^{2}$, this variable was kept in the model (Box and Benhken, 1960). Just linear and quadratic effects of temperature affected SV.
Some other terms (linear effects of moisture and reagent level, quadratic of moisture and interactions of moisture and temperature with reagent level), although nonsignificant, were kept because also contributed to adjustment of model (Lundstedt et al., 1998). Color was influenced by linear, quadratic and interaction effects of reagent level and temperature and by quadratic effect of moisture.

All the models presented $\mathrm{R}^{2}$ higher than 0.86 and nonsignificant lack of fit, indicating that they adjusted well to the experimental data. Regression model of color presented the smallest coefficient of variation $(1.10 \%)$, while WRC and swollen volume obtained 5.54 and $5.72 \%$, respectively. Linear and quadratic effects of temperature and interactions of temperature and reagent level with moisture influenced WRC. Just linear and quadratic effects of temperature affected swollen volume. Color was influenced by linear, quadratic effects and of interaction reagent level and temperature and quadratic of moisture.

Table 2 - Regression Coefficients and Analysis of Variance (ANOVA) of the simplified mathematical models ${ }^{\mathrm{a}}$ of the dependent variables.

\begin{tabular}{|c|c|c|c|c|}
\hline \multirow{2}{*}{\multicolumn{2}{|c|}{ Coefficients }} & \multirow[b]{2}{*}{ Water Retention Capacity } & \multicolumn{2}{|c|}{ Dependent Variables } \\
\hline & & & Swollen Volume & Brightness $\left(\mathbf{L}^{*}\right)$ \\
\hline \multirow{3}{*}{ Linear } & $\beta_{0}$ & $3.520^{*}$ & $4.488^{*}$ & $63.127^{*}$ \\
\hline & $\beta_{1}$ & $-0.058^{\mathrm{b}}$ & $-0.022^{\mathrm{c}}$ & $6.267^{*}$ \\
\hline & $\beta_{2}$ & $0.015^{\mathrm{b}}$ & $-0.106^{c}$ & - \\
\hline \multirow{3}{*}{ Quadratic } & $\beta_{3}$ & $-0.369 *$ & $-0.404^{*}$ & $-6.050 *$ \\
\hline & $\beta_{11}$ & $0.287^{\mathrm{c}}$ & - & $0.352 *$ \\
\hline & $\beta_{22}$ & - & $0.380^{\mathrm{c}}$ & $-0.603 *$ \\
\hline \multirow{4}{*}{ Interaction } & $\beta_{33}$ & $0.432 *$ & $0.500 *$ & $0.882 *$ \\
\hline & $\beta_{12}$ & $0.412 *$ & $0.202^{\mathrm{c}}$ & - \\
\hline & $\beta_{13}$ & - & $-0.172^{\mathrm{c}}$ & $1.235^{*}$ \\
\hline & $\beta_{23}$ & $-0.337 *$ & - & - \\
\hline \multicolumn{2}{|c|}{$\mathrm{R}^{2}$} & 0.8976 & 0.8606 & 0.9990 \\
\hline \multicolumn{2}{|c|}{ Standard Deviation } & 0.5041 & 0.5034 & 6.6480 \\
\hline \multicolumn{2}{|c|}{$\begin{array}{l}\text { Coefficient of } \\
\text { Variation }(\%)\end{array}$} & 5.5422 & 5.7164 & 1.1041 \\
\hline \multicolumn{2}{|c|}{ Lack of fit (p) } & 0.2197 & 0.3284 & 0.1749 \\
\hline
\end{tabular}


Water Retention Capacity (WRC)

The tendency for higher values of WRC (Fig. 1 and 2) was located in the area of lower extrusion temperature $\left(110^{\circ} \mathrm{C}\right)$ and higher moisture $(32 \%)$ and reagent level (7\%). Probably, in more drastic experimental conditions (high temperature and low moisture), an excessive structural disruption occurred, destroying the porous cell wall conformation obtaining lower WRC, since the fragmentation of fiber matrix reduced interstitial space, besides destroying the structures responsible for interaction with water.

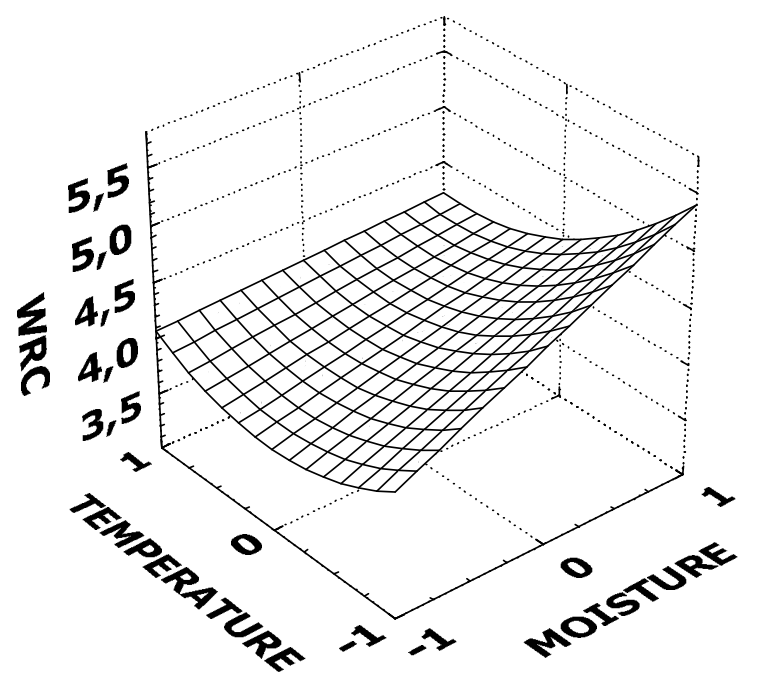

Figure 1 - Effect of extrusion temperature and feed moisture on water retention capacity (WRC) of oat hulls (reagent fixed at +1 level).

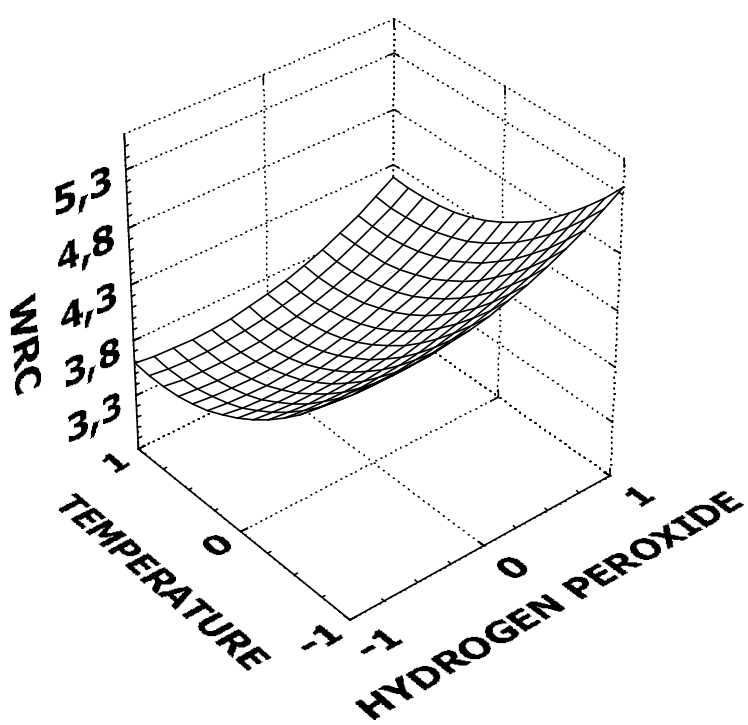

Figure 2 - Effect of extrusion temperature and hydrogen peroxide level on water retention capacity (WRC) of oat hulls (moisture fixed at +1 level). 
Larrea et al., (1997) and Ning et al., (1991) also observed that WRC of fiber decreased with the increase of extrusion temperature. According to these authors, the accentuated reduction of the particles size, promoted by matrix collapse, reduced WRC. High extrusion temperatures, as well as drastic conditions during the process, could be the main reasons of this collapse. According to Harper (1986), materials with low moisture content request higher mechanical energy to promote flow inside of extruder. Higher mechanical energy results in higher temperatures causing higher structural disruption and, consequently, reducing WRC.

In relation to the effect of hydrogen peroxide (Fig. 2), there indication that proceeding besides the studied superior value (7\%), would cause an increase in WRC. Hydrogen peroxide and sodium hydroxide present important influence in increasing of this property. The first acts in the lignin degradation by removal through solubilization and/or structural modification and also decreasing cellulose crystallinity. Second promote modification of fiber structure allowing water penetration and retention (Gould, 1985; Ning et al., 1991).

\section{Swollen Volume (SV)}

Lower extrusion temperatures caused an increase in the SV (Fig. 3) that would be explained by the destruction of structures responsible by interaction with the water, in higher temperatures. The interstitial space volume available to retain water is also very important to increase SV and can be reduced by matrix collapse at higher temperatures.

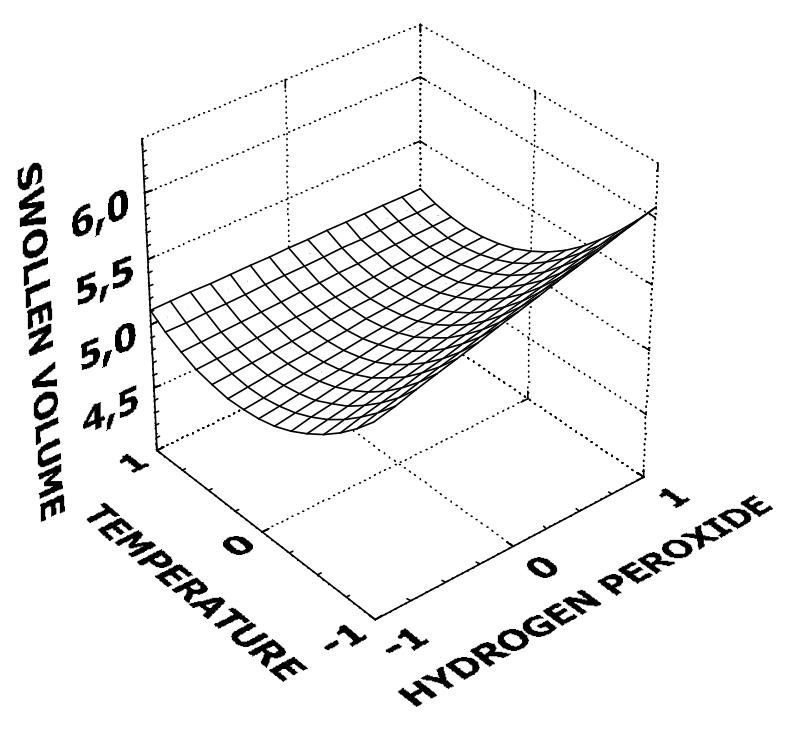

Figure 3 - Swollen volume (SV) as a function of extrusion temperature and hydrogen peroxide level (moisture fixed at +1 level).

Larrea et al. (1997) also verified that the increase, from 125 to $225^{\circ} \mathrm{C}$, in the extrusion temperature of rice hulls, promoted a significant decrease of swollen volume. According to Gould (1985) and Ning et al. (1991), alkaline hydrogen peroxide degrades lignin by removal for solubilization and/or structural modification, at the same time that modifies cellulose crystallinity, increasing swollen capacity. However, in this study, reagent action was not significant for this property (Table 2 and Fig. 3), probably because the experimental strip was too narrow to allow such modification. 


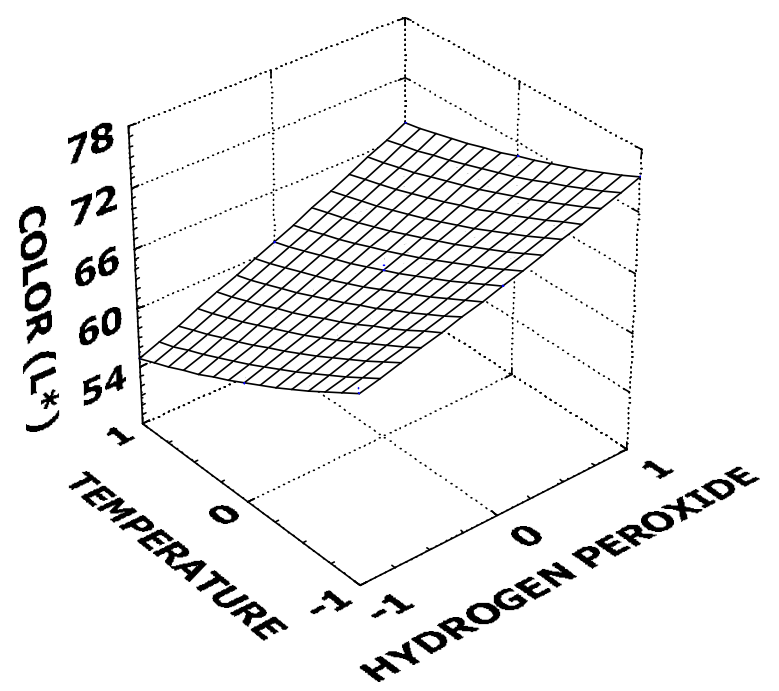

Figure 4 - Effect of treatment on color $\left(\mathrm{L}^{*}\right)$ of oat hulls (moisture fixed at +1 level).

\section{Color - Brightness ( $\left.\mathrm{L}^{*}\right)$}

Brightness increased when extrusion temperature was reduced and reagent level was increased (Fig. 4). Clearer products in these conditions were obtained. Oat hulls tan coloration is an important limitation for their application in food products, because restricts addition levels due to noncharacteristic tonalities that confers to the products which are incorporate (Rodriguez et al., 1992).

\begin{abstract}
Displacement for More Promising Experimental Area

Table 3 showed the features of oat hulls extruded at temperatures lower than $110^{\circ} \mathrm{C}$, pointed as more promising experimental area by results presented before. Reducing extrusion temperature up to $90^{\circ} \mathrm{C}$ increased the WRC and SV (5.14g water/g sample for WRC and $6.23 \mathrm{~mL} / \mathrm{g}$ sample for $\mathrm{SV}$ ), as pointed by the exploratory design. When temperature was $80^{\circ} \mathrm{C}$, however, these values decreased. In relation to the color, lower extrusion temperatures generated higher $\mathrm{L}^{*}$ value, therefore, clearer products were obtained at $80^{\circ} \mathrm{C}$.
\end{abstract}

Table 3 - Water retention capacity (WRC), swollen volume (SV) and color ( $\left.\mathrm{L}^{*}\right)$ of the extrudates obtained at different extrusion temperatures.

\begin{tabular}{ccccc}
\hline \multirow{2}{*}{ Assays } & $\begin{array}{c}\text { Independent variable } \\
\text { Temperature }\left({ }^{\circ} \mathrm{C}\right)\end{array}$ & $\begin{array}{c}\text { WRC } \\
(\mathrm{g} / \mathrm{g})\end{array}$ & $\begin{array}{c}\mathrm{SV} \\
(\mathrm{mL} / \mathrm{g})\end{array}$ & $\mathrm{L}^{*^{2}}$ \\
\cline { 3 - 5 } & 100 & $4.19^{\mathrm{a}}$ & $5.14^{\mathrm{b}}$ & $67.38^{\mathrm{a}}$ \\
2 & 90 & $5.14^{\mathrm{b}}$ & $6.23^{\mathrm{c}}$ & $69.87^{\mathrm{b}}$ \\
3 & 80 & $4.19^{\mathrm{a}}$ & $4.88^{\mathrm{a}}$ & $72.19^{\mathrm{c}}$ \\
\hline
\end{tabular}

Means, in the same column, followed by the same letter are not significantly different (Tukey's test, $\mathrm{p}<0.05$ ).

${ }^{1}=$ moisture $=32 \%$ and reagent level $=7 \% ;{ }^{2}=$ Brightness $*$.

\section{pH}

Modified oat hulls presented $\mathrm{pH}$ 8.56. Due to the interaction among fiber and alkali during extrusion, the $\mathrm{pH}$ of extrudate was substantially different from the initial $\mathrm{pH}$. According to Artz et al. (1990) temperature, pressure and shear during the process were responsible for base consumption in reactions with fiber components. Inglett (1995) produced an ingredient from oat hulls disintegration with solution of alkaline 
hydrogen peroxide. This ingredient, after several washes, presented $\mathrm{pH} 8.5$, which was in agreement with the current study.

\section{Comparative Evaluation of the Effect of the Treatment in the Characteristics of Oat Hulls}

Treatment improved functional properties of oat hulls in comparison with untreated material (Table 4). There was an increase after treatment of 70 and $55 \%$ in WRC and swollen volume, respectively. These values were in agreement with the idea that cells of these treated materials presented more open internal structure with increased surface porosity, which facilitated the penetration of water (Gould et al., 1990; Ning et al., 1991).

Untreated oat hulls presented darker coloration $\left(\mathrm{L}^{*}=67.52\right)$ than treated hulls $\left(\mathrm{L}^{*}=69.87\right)$. Although this was a small difference, it was considered important since this material was treated with sodium hydroxide and high temperatures, which were responsible for the darkening of the material. If hydrogen peroxide had not been used the obtained product would be, probably, very dark, and therefore, sensory unacceptable.

Table 4 - Effect of treatment in water retention capacity (WRC), swollen volume (SV) and color of oat hulls.

\begin{tabular}{lccc}
\hline & $\begin{array}{l}\text { WRC } \\
(\mathrm{g} / \mathrm{g})\end{array}$ & $\begin{array}{c}\text { SV } \\
(\mathrm{mL} / \mathrm{g})\end{array}$ & $\begin{array}{c}\text { Brightness } \\
\left(\mathrm{L}^{*}\right)\end{array}$ \\
\hline Untreated $^{1}$ & $3.03^{\mathrm{a}}$ & $4.03^{\mathrm{a}}$ & $67.52^{\mathrm{a}}$ \\
Treated $^{1}$ & $5.14^{\mathrm{b}}$ & $6.23^{\mathrm{b}}$ & $69.87^{\mathrm{b}}$ \\
\hline
\end{tabular}

Means, in the same column, followed by the same letter are not significantly different (Tukey's test, $\mathrm{p}<0.05$ ).

${ }^{1}=7 \%$ hydrogen peroxide, $32 \%$ moisture and $90^{\circ} \mathrm{C}$ extrusion temperature.

\section{Control Experiments}

The chemical treatment with alkaline reagent promoted higher WRC and swollen than extrusion process only. However, both isolated treatments produced lower values than associated treatments (Table 5).

Table 5 - Water retention capacity (WRC) and swollen volume (SV) of untreated and treated hulls in different experimental conditions.

\begin{tabular}{lcc}
\hline \multicolumn{1}{c}{ Treatment } & $\begin{array}{l}\text { WRC } \\
(\mathrm{g} / \mathrm{g})\end{array}$ & $\begin{array}{c}\mathrm{SV} \\
(\mathrm{mL} / \mathrm{g})\end{array}$ \\
\hline Untreated $_{\text {Extrusion (without reagent) }}{ }^{1}$ & $3.03^{\mathrm{a}}$ & $4.03^{\mathrm{a}}$ \\
Chemical (without extrusion) $^{2}$ & $4.30^{\mathrm{b}}$ & $4.92^{\mathrm{b}}$ \\
Extrusion and chemical $^{3}$ & $4.87^{\mathrm{c}}$ & $4.96^{\mathrm{c}}$ \\
\hline
\end{tabular}

Means, in the same column, followed by the same letter are not significantly different (Tukey's test, $\mathrm{p}<0.05$ ).

${ }^{1}=90^{\circ} \mathrm{C}, 32 \%$ moisture; ${ }^{2}=7 \%$ hydrogen peroxide, $32 \%$ moisture; ${ }^{3}=7 \%$ hydrogen peroxide, $32 \%$ moisture, $90{ }^{\circ} \mathrm{C}$.

Ning et al. (1991) treated corn fiber with alkali and also associated this treatment with extrusion. Alone, the alkaline treatment increased WRC of $2.94 \mathrm{~g} / \mathrm{g}$ sample (untreated fiber) to $3.64 \mathrm{~g} / \mathrm{g}$ sample (treated fiber). When the alkaline treatment was associated to the extrusion, WRC was of 3.45 $\mathrm{g} / \mathrm{g}$ sample. This decrease was nonsignificant $(\mathrm{p}<0.05)$. However, according to Qian and Ding (1996), after extrusion, the amount of available hydroxyl groups and porous size decreased, resulting in less swelling of fiber and less retaining water. Another study (Artz et al., 1990) performed to characterize the effect of extrusion process in the functional properties of fiber concluded that the effect was little evident. This could be due to the short time inside extruder to allow severe chemical changes, particularly considering that this material was very resistant to modification, confirming, therefore, the need of associate chemical treatments to enhance the fiber modification achieved via extrusion.

\section{CONCLUSION}

The treatment with alkaline hydrogen peroxide associated with extrusion promoted important modification in the oat hulls fiber. The processing 
in conditions of $7 \%$ hydrogen peroxide, $32 \%$ moisture and $90^{\circ} \mathrm{C}$ extrusion temperature increased in $70 \%$ the WRC and 55\% the swollen volume when compared to untreated hulls. With this treatment, was possible to obtain a high-fiber product $(80 \%)$ and clear coloration that could be used as noncaloric ingredient in a variety of formulations. Although the increment in hydration properties was smaller than those obtained by Inglett (1995), the proposed process presented advantage of not generating residues, besides using a short time of reaction.

\section{RESUMO}

Um delineamento fatorial incompleto $3^{3}$ foi utilizado para estudar o efeito do tratamento com peróxido de hidrogênio alcalino associado à extrusão sobre algumas propriedades funcionais da fibra da casca de aveia. As variáveis do tratamento avaliadas incluíram teor de peróxido de hidrogênio (\%), umidade da amostra (\%) e temperatura de extrusão $\left({ }^{\circ} \mathrm{C}\right)$. A análise de variância (ANOVA) mostrou que a temperatura foi a variável mais importante para as propriedades de hidratação. Os maiores valores de capacidade de retenção de água (CRA) e volume de intumescimento foram obtidos na condição de $7 \%$ de peróxido de hidrogênio, $32 \%$ de umidade e $90^{\circ} \mathrm{C}$ de temperatura, obtendo um incremento de $70 \%$ na CRA e $55 \%$ no volume de intumescimento. A medida instrumental de cor foi usada para analisar as modificações ocorridas neste parâmetro. $\mathrm{O}$ mais alto valor de luminosidade foi alcançado com maior nível de peróxido de hidrogênio (7\%), obtendo-se, nessa condição, produtos mais claros. Ensaios realizados para controle mostraram que tanto a extrusão quanto o tratamento químico tiveram efeito nas propriedades avaliadas, e que o efeito conjunto foi superior ao de cada um isoladamente. As modificações ocorridas nas fibras foram acompanhadas indiretamente, através das propriedades de hidratação.

\section{REFERENCES}

American Association of Cereal Chemists (1990), Approved Methods of the American Association of Cereal Chemists. AACC, St. Paul.
Artz, W.; Warren, C. and Villota, R. (1990), Twinscrew extrusion modification of a corn fiber and corn starch extruded blend. Journal of Food Science, 55, 746-754.

Box, G. E. P. and Benhken, D. W. (1960), Some new three level designs for the study of quantitative variables. Technometrics, 2, 455-475.

Gould, M. (1985), Enhanced polysaccharide recovery from agricultural residues and perennial grasses treated with alkaline hydrogen peroxide. Biotechnology and Bioengineering, 27, 893-896.

Gould, J. M.; Jasberg, B. K.; Dexter, L. B.; Hsu, J. T.; Lewis, S. M. and Fahey, G. C. (1989), High-fiber, noncaloric flour substitute for baked foods. Properties of alkaline peroxide-treated lignocellulose. Cereal Chemistry, 66, 201-205.

Gould, J. M. (1989), Alkaline peroxide treatment of agricultural byproducts. U.S. Patent number 4,806,475; February 21.

Gould, J. M.; Jasberg, B. K. and Dexter. L. (1990), Effects of alkaline peroxide-treated fiber ingredients on mixograph properties of wheat flour dough. Lebensmittel Wissenschaft und Technologie, 23, 358-360.

Harper, J. M. (1986), Extrusion texturization of foods. Food Technology, 40, 70-76.

Inglett, G. E. (1995), Dietary fiber gels for preparing calorie reduced foods. U.S. Patent application serial number 08/563,834; November 28.

Larrea, M. A.; Grossmann, M. V. E.; Beléia, A. P. and Tavares, D. Q. (1997), Changes in water absorption and swollen volume in extruded alkaline peroxide pretreated rice hulls. Cereal Chemistry, 74, 98-101.

Lue, S.; Hsieh, F. and Huff, H. E. (1991), Extrusion cooking of corn meal and sugar beet fiber: effects on expansion properties, starch gelatinization, and dietary fiber content. Cereal Chemistry, 68, 227-234.

Lundstedt, T. et al. (1998), Experimental design and optimization. Chemometrics and Intelligent Laboratory System, 42, 3-40.

Matz, S. A. (1969), Oats. In: Cereal Science. SA. Matz, ed. Avi Publishing Company, Westport, CT., 78-96.

Ning, L.; Villota, R. and Artz, W. E. (1991), Modification of corn fiber through chemical treatments in combination with twin-screw extrusion. Cereal Chemistry, 68, 632-636.

Park, H.; Seib, P. A. and Chung, O. K. (1997), Fortifying bread with a mixture of wheat and psyllium husk fiber plus three antioxidants. Cereal Chemistry, 74, 207-211.

Ramaswamy, S. R. (1988), Dietary fiber and method of making. European Patent Application 0283589 A1 ; September 28.

Robertson, J. A. (1998), Application of plant-based byproducts as fiber supplements in processed foods. Recent Res. Development in Agricultural \& Food Chemistry, 2, 705-717. 
Robertson, J. A. et al. (2000), Hydratation properties of dietary fibre and resistent starch: a european collaborative study. Lebensmittel Wissenschaft und Technologie, 33, 72-79.

Rodriguez, J. L.; Cerezal, P. and Larrauri, J. A. (1992), Caracterización de los residuos deshidratados obtenidos durante la elaboración del colorante de remolacha. Alimentaria, 65-67.

Stephen, M. A.; Dahl, W. J.; Johns, D. M. and Englyst, H. N. (1997), Effect of oat hull fiber on human colonic function and serum lipids. Cereal Chemistry, 74, 379-383.

Qian, J. Y. and Ding, X. L. (1996), Effect of twinscrew extrusion on the functional properties of soya fiber. Journal Science Food Agriculture, 71, 64-68.

Received: December 04, 2003; Revised: March 16, 2004; Accepted: July 14, 2004. 